\title{
Activation of coagulation and fibrinolysis during maximal physical exercise
}

Citation for published version (APA):

Hamulyak, K., Brommer, E. J. P., Devilee, P. P., \& Hemker, H. C. (1984). Activation of coagulation and fibrinolysis during maximal physical exercise. International Journal of Sports Medicine. Supplement, 5, 6465. https://doi.org/10.1055/s-2008-1025953

Document status and date:

Published: 01/01/1984

DOI:

10.1055/s-2008-1025953

Document Version:

Publisher's PDF, also known as Version of record

\section{Please check the document version of this publication:}

- A submitted manuscript is the version of the article upon submission and before peer-review. There can be important differences between the submitted version and the official published version of record. People interested in the research are advised to contact the author for the final version of the publication, or visit the DOI to the publisher's website.

- The final author version and the galley proof are versions of the publication after peer review.

- The final published version features the final layout of the paper including the volume, issue and page numbers.

Link to publication

\footnotetext{
General rights rights.

- You may freely distribute the URL identifying the publication in the public portal. please follow below link for the End User Agreement:

www.umlib.nl/taverne-license

Take down policy

If you believe that this document breaches copyright please contact us at:

repository@maastrichtuniversity.nl

providing details and we will investigate your claim.
}

Copyright and moral rights for the publications made accessible in the public portal are retained by the authors and/or other copyright owners and it is a condition of accessing publications that users recognise and abide by the legal requirements associated with these

- Users may download and print one copy of any publication from the public portal for the purpose of private study or research.

- You may not further distribute the material or use it for any profit-making activity or commercial gain

If the publication is distributed under the terms of Article $25 \mathrm{fa}$ of the Dutch Copyright Act, indicated by the "Taverne" license above, 
Int. J. Sports Med. 5 (1984) 64-65 Supplement

(c) Georg Thieme Verlag Stuttgart · New York

\author{
Activation of Coagulation and Fibrinolysis during Maximal Physical Exercise \\ K. Hamulyák ${ }^{1}$, E.J.P. Brommer ${ }^{2}$,P.P. Dévilée ${ }^{1}$, and H.C. Hemker ${ }^{1}$ \\ 1 Department of Biochemistry, Faculty of Medicine, University of Limburg, Maastricht, The Netherlands \\ ${ }^{2}$ Gaubius Institute TNO, Leiden, The Netherlands
}

\section{Introduction}

Changes in haemostatic parameters induced by physical exercise have been described in the literature by many authors $(1-6)$. There is general agreement that physical exercise elicits a rise in the factor VIII clotting activity and in the fibrinolytic activity of blood. The latter has been attributed to a release of plasminogen activator into the circulating blood, which accounts for the shortening of the euglobulin clot lysis time, an increase in the lysis zone on fibrin plates (7) and also for an increase in extrinsic plasminogen activator as measured by immunoradiometric assay (8).

Most authors claim that a significant increase in the fibrinolytic activity does occur only after exhaustive physical exercise.

At present, the general view is that despite increased level of plasminogen activator, plasmin formation only occurs in the presence of fibrin (9). The most sensitive parameter of fibrin formation in vivo is the level of fibrinopeptide A (11). Only a few reports in the literature have studied fibrinopeptide A levels.

In this study we investigated several parameters of coagulation and fibrinolysis during graded exercise, in order to elucidate to which degree coagulation and fibrinolysis are activated and to see whether there are mechanisms counteracting this activation state of the haemostatic reaction.

\section{Materials and Methods}

Exercise protocol: We investigated six healthy male volunteers. Exercise was performed on a bicycle ergometer, starting with a work load of 100 Watt, every three minutes the load was increased by 50 Watt until exhaustion. Blood was processed to obtain platelet-poor plasma in a way to minimize in vitro changes.
Lactate concentrations were determined in serum by an enzymatic-electrochemical method. Racine 1975 (10).

Fibrinopeptide $A$ levels: The FPA levels were measured by radio-immuno-assay, using a simplified procedure as has been described by Van Hulsteijn et al. (11).

Plasminogen activator levels were measured in a bovine plasminogen-rich fibrin plate and expressed in $\mathrm{mm}^{2}$ lysis zone (7).

Antithrombin III and $\alpha_{2}$-macroglobulin were quantited in citrated plasma by immunodiffusion in partigen plates according to prescriptions of the manufacturer (Behring Werke A.G., Marburg/Lahn, West Germany).

Haematocrit, thrombin clotting time, reptilase time, FVIII clotting activity, fibrinogen and fibrinogen degradation products were measured according to standard procedures.

Statistics: a paired two-sides student's T test was applied.

\section{Results and Discussion}

The results are summarized in Table 1. The lactate concentration rose significantly in all subjects. The haematocrit level showed a mean increase of $7.5 \%$ Fibrinogen levels increased in parallel with the haematocrit.

The thrombin clotting time did not change during exercise. Fibrinogen degradation products were undetectable in an Ouchterlony immunodiffusion method. However, after exercise we found very high levels of fibrinopeptide A (FPA), suggesting thrombin formation and partial proteolysis of fibrinogen by thrombin. The applied sampling procedure excludes the possibility of an important contribution of thrombin formed after sampling. We speculate therefore that thrombin formation in vivo occurs during exercise.

Table 1

\begin{tabular}{|c|c|c|c|c|c|}
\hline$N=6$ & before & & $\begin{array}{l}\text { s and range } \\
\text { after }\end{array}$ & & p-value \\
\hline fibrinogen & $2.6 \mathrm{gr} / \mathrm{l}$ & $(2.2-2.9)$ & $2.8 \mathrm{gr} / \mathrm{l}$ & $(2.3-3.1)$ & N.S. \\
\hline FPA & $5.6 \mathrm{ng} / \mathrm{ml}$ & $(1.6-14.8)$ & $157.4 \mathrm{ng} / \mathrm{ml}$ & $(9.5-1200)$ & $<0.01$ \\
\hline Thrombin time & $18.2 \mathrm{sec}$ & $(17.1-20.3)$ & $18.3 \mathrm{sec}$ & $(16.9-19.6)$ & N.S. \\
\hline Reptilase time & $17.0 \mathrm{sec}$ & $(15.4-19.8)$ & $17.5 \mathrm{sec}$ & $(16.3-20.4)$ & $<0.02$ \\
\hline FVIII:C & $0.84 \mathrm{U} / \mathrm{ml}$ & $(0.55-1.04)$ & $2.4 \mathrm{U} / \mathrm{ml}$ & $(1.55-3.00)$ & $<0.05$ \\
\hline FDP & negative & & negative & & \\
\hline Plg-act. & $163.4 \mathrm{~mm}^{2}$ & $(49-272)$ & $306.4 \mathrm{~mm}^{2}$ & $(83-573)$ & $<0.001$ \\
\hline AT $\|$ & $33.4 \mathrm{mg} \%$ & $(31.2-36.8)$ & $37.1 \mathrm{mg} \%$ & $(34.5-42.3)$ & $<0.001$ \\
\hline$\alpha_{2}-M$ & $211.9 \mathrm{mg} \%$ & $(190-242.3)$ & $261.1 \mathrm{mg} \%$ & $(218.3-294.6)$ & $<0.001$ \\
\hline Lactate & $1.8 \mathrm{mmol} / \mathrm{l}$ & $(1.27-2.94)$ & $10.6 \mathrm{mmol} / \mathrm{l}$ & $(8.14-12.58)$ & $<0.001$ \\
\hline Haematocrit & 42.8 & $(38-44)$ & 46.0 & $(40-51)$ & $<0.01$ \\
\hline
\end{tabular}

FPA: fibrinopeptide A

FDP: fibrin(ogen) degradation products

Plg-act. plasminogen activator 


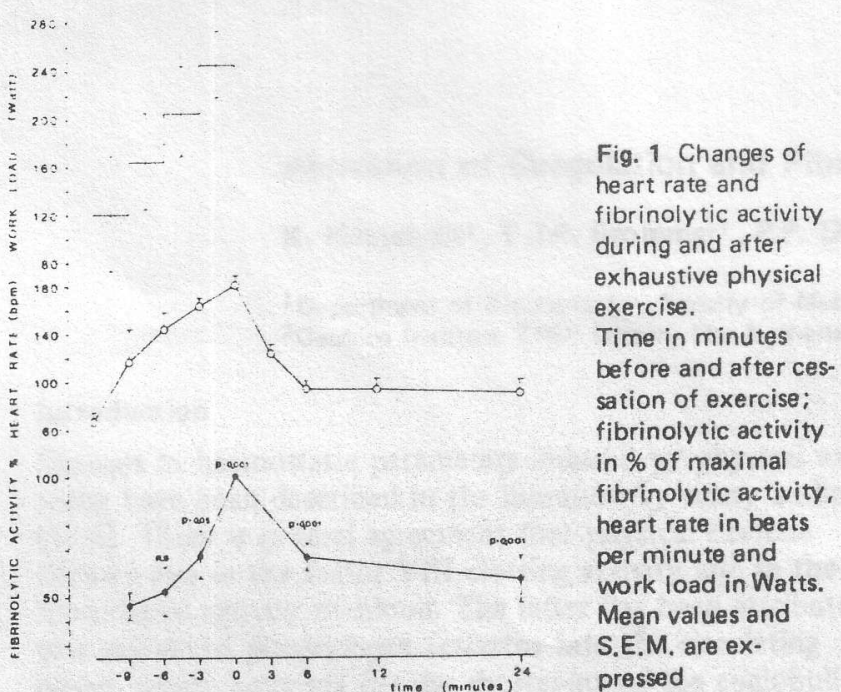

The antithrombin III concentration increased by $11 \%$ in a quantitative determination, concomitant with the rise in haematocrit. Our results are in agreement with the observation of Hyers (4) who found a $20-30$ fold increase in FPA after physical exercise, but in disagreement with the findings of Marsh et al. (6). These conflicting results may be explained by different intensities of exercise. Factor VIII clotting activity (FVIII' C) increased from $0.84 \mathrm{U} / \mathrm{ml}$ to $2.4 \mathrm{U} / \mathrm{ml}$. An exercise-induced increase of factor VIII: $C$ has been reported by several authors in the literature (1). Brown (1) described a disproportionate rise in factor VIII procoagulant activity and suggested that this can be due to thrombin formation as a consequence of physical exercise. This would be compatible with our findings.

In fig. 1 data on the fibrinolytic activity, heart rate and work load are summarized. As can be seen from this figure, a gradual increase in the fibrinolytic activity occurred during the last nine minutes before exhaustion was reached. Other groups have reported that only very strenuous exercise will raise the fibrinolytic activity. Davis et al. (3) postulated that below 70 to $80 \%$ of the maximum heart rate little change can be expected. Previously, Rosing et al. (5) had observed that 30 minutes of treadmill exercise with an intensity corresponding to $40 \%$ maximal oxygen uptake, caused only a slight increase in fibrinolytic activity, which remained within normal daily fluctuations. However, recently Wiman et al. (12) demonstrated a gradual increase of plasminogen activator concentration during exercise. After cessation of exercise the fibrinolytic activity dropped fast as has been described by others $(4,5)$. After exercise both plasmin- $\alpha_{2}$ antiplasmin and plasmin- $\alpha_{2}$ macroglobulin complexes were demonstrated by crossed immunoelectrophoresis (results not shown). Though this suggested the formation of plasmin, no fibrin(ogen) degradation products could be demonstrated. The formed plasmin is presumably rapidly neutralized. These results suggest that upon maximal physical exercise activation of both the coagulation and the fibrinolytic pathways occur. If these changes are partially due to plasmin formation in vitro, it must be concluded that these changes are enhanced by exercise. Recently we discovered that after exercise free fast acting in- hibitors of plasminogen activator disappear (13). In the absence of these inhibitors some plasmin may be formed, even when no fibrin is present (14). Regular strenuous physical exercise may deplete endothelial stores of plasminogen activator (15), leaving the possibility of fibrin deposition without securing its removal.

It remains to be established if this short lasting state of activation of the haemostatic reaction is unfavourable, especially in arteriosclerotic patients.

\section{Acknowledgement}

The authors wish to achnowledge gratefully the help and suggestions of Dr. F.T.J. Verstappen, Department of Physiology, Faculty of Medicine, University of Limburg, Maastricht, The Netherlands, in preparing this manuscript.

\section{References}

1 Brown J.E., Baugh R.F., Hougie C.: Effect of exercise on the factor VIII complex. A Correlation of the von Willebrand antigen and factor VIII coagulant antigen increase. Thrombosis Res. 15: 61-67, 1979.

2 Iatridis S.G., Ferguson J.W.: Effect of physical exercise on blood clotting and fibrinolysis. Journal of Applied Physiology vol 18 , no 2 : $337-344,1963$.

3 Davis G.L., Abildgaard C.F., Bernauer E.M., Britton M.: Fibrinolytic and hemostatic changes during and after maximal exercise in males. Journal of Applied Physiology vol 40, no 3, 287-292, 1976.

4 Hyers T.M., Martin B.J., Pratt D.S., Dreisin R.B., Franks J.J.: Enhanced thrombin and plasmin activity with exercise in man Journal of Applied Physiology 48(5): 821-825, 1980.

5 Rosing D.R., Brakman P., Redwood D.R., Goldstein R.E., Beiser G.D., Astrup T., Epstein S.E.: Blood fibrinolytic activity in man. Diurnal variation and the response to varying intensities of exercise. Circulation Res. vol 27: 171-184, 1970.

6 Marsh N.A., Gaffney P.J.: Exercise-induced fibrinolysis - Fact or Fiction? Thromb Haemostas. 48: 201-203, 1982.

7 Kluft C.: Studies on the fibrinolytic system in human plasma. Ouantitative determination of plasminogen activators and proactivators. Thromb Haemostas 41: 365-383, 1979.

8 Rijken D.C., Juhan-Vague J., de Cock F., Collen D.: Measurement of human tissue-type plasminogen activator by a two site immunoradiometric assay. J Lab Clin Med vol 101, no 2, 274284, 1983.

9 Collen D.: On the regulation and control of fibrinolysis; Edward Kowalski Memorial Lecture. Thromb Haemostas. 43: 77-89, 1980.

10 Racine P., Klenk W.O, Kochsiek K.: Rapid lactate determination with an electrochemical enzymatic sensor: clinical usuability and comparative measurements. Z Klin Chem Klin Biochem 13: $5333-5339,1975$.

11 Hulsteijn L.H. v., Briët E., Bertina R.: Simplified Procedure for the assay of Fibrinopeptide A in plasma. Thrombosis Res 21: 207-213, 1981.

12 Wiman B., Mellbring G., Ranby M.: Plasminogen activator release during venous stasis and exercise as determined by a new specific assay. Clin Chim Acta 127: 279-288, 1983.

13 Brommer E.J.P., Verheyen J.H., Rijken D.C.: Masking of fibrinolytic response to DDAVP, venous occlusion and exercise by fast acting inhibitors of plasminogen activator. In press.

14 Nieuwenhuizen W., Voskuilen M., Traas E.W., Hoegee-de Nobel E., Verheyen J.H.: Kinetics of the tissue type plasminogen activator mediated activation of plasminogen. Influence of $\mathrm{CNBr}^{-}$ fibrin(ogen) fragment FCB-2 and different forms of plasminogen. In: Fibrinogen, structure and function. Ed. A. Henschen, Walter de Gruyter, Berlin 1984.

15 Keber D., Stegnar M., Keber I., Accetto B.: Influence of moderate and strenuous daily physical activity on fibrinolytic activity of blood: possibility of plasminogen activator stores depletion. Thromb Haemostas 41: 745, 1979. 